\title{
The importance of viral foodborne illnesses: short review
}

\begin{abstract}
Virus borne disease arises from contaminated food which can occur in all stages of food handling. Recently viral cases have been a load issue and significantly causes to most food borne illnesses. Thus the need of their fast detection and finding the disinfecting methods is sought.
\end{abstract}

Keywords: Viral food borne illnesses; GMP; Food handling; GAP; Hot Cell DNA; NORO viruses; GHP; Preservation
Volume 4 Issue 3 - 2016

\author{
Muhammad Usman Khan,' Shilan \\ Rashidzadeh, ${ }^{2}$ Mohammad Ali Shariati ${ }^{3}$ \\ 'Doctoral Research Assistant Bioproducts, Sciences and \\ Engineering Laboratory Washington State University, USA \\ ${ }^{2}$ Research Department, LLC Science \& Education, and \\ Researcher, Russia and All Russian Research Institute of \\ Phytopathology, Russia \\ ${ }^{3}$ Department of Food Science and Technology, Gorgan Payame \\ Noor University, Iran
}

\begin{abstract}
Correspondence: Muhammad Usman Khan, Doctoral Research Assistant Bioproducts, Sciences and Engineering Laboratory Washington State University, Tri-Cities 2710, Crimson Way, Richland,WA-99354 United States of America, Email engineer_usman_khan@yahoo.com
\end{abstract}

Received: November 05, 2016 | Published: December 28, 2016
Abbreviations: HAstV, Human Astrovirus; NoV, Norovirus; HRV, Human Rotavirus; GMP, Good Manufacturing Practice; GAP, Good Agriculture Practice

\section{Introduction}

Shelf life is an important concern when food produces. About all types of foodstuff such as beer, ${ }^{1}$ mushrooms varieties, ${ }^{2}$ medical plants, ${ }^{3}$ cookies, ${ }^{4}$ bread and its new additives ${ }^{5}$ which lead to new formulas; destroying diverse microorganisms is too important. Since viruses create critical risk in case of consuming virus contaminated food, all the food handling stages must be consistent with standard and auditing. The fact of introducing viral disease in foodstuffs has studied fewer. NORO viruses including (HAdV), human astrovirus (HAstV), norovirus (NoV), and human rotavirus (HRV) ${ }^{6}$ are the most common viral disease reasons. ${ }^{6}$

Mostly viral outbreaks, the trace of an infected handler has found instead of mechanically food handling. ${ }^{7}$ Chiefly, food borne disease because of viral problems arises from an infected person during process not followed by heat-treating afterwards.

Viruses are highly dependent to enter a cell to create its vital compounds using hot cell DNA. ${ }^{8}$ Furthermore, viruses are heatresistant and their detecting methods should be sensitive. ${ }^{9}$

Noting to issues, it is underling that improving hygienic programs in food factories is the main and key solutions. Heating has more lethality power than UV and radio frequency ${ }^{10}$ in destroying viruses. In this regards, manufacturers must pay attention to the complete installation of both good agriculture practice (GAP) and good manufacturing practice (GMP) to avoid contamination by means of viruses. Besides, HACCP must assure that plenty control on viruses is handling. Koompas and Duizer proposed that informing about viruses with improving of detecting methods as well as attention to viruses when setting up of (GHP, GMP, and HACCP) can decrease virus risk in food handling.

\section{Conclusion}

Different types of viruses may consider as prime concern. The importance of detection to reduce virus transmission to foods as well as improving GHP, GMP and GAP are too important to reduce viral diseases. It lets better surveying, increasing safety of food materials.

\section{Acknowledgments}

None.

\section{Conflicts of interest}

None.

\section{References}

1. Ghafari Z, Hojjatoleslamy M, Shokrani R, et al. Use of date syrup as a sweetener in non alcoholic beer: sensory and rheological assessment. Journal of Microbiology Biotechnology and Food Sciences. 2013;3(2):182-184.

2. Akbarirad H, Kazemeini, SM, Shariaty MA. Deterioration And Some of Applied Preservation Techniques For Common Mushrooms (Agaricus Bisporus, Followed by Lentinus Edodes, Pleurotus Spp.). Journal of Microbiology Biotechnology and Food Sciences. 2013;2(6):2398.

3. Usman Khan M, Majeed M, Tayyab M, et al. Chemical and Nutritional Properties of Some Commercial Available Corn and Wheat Products. Journal of Microbiology Biotechnology and Food Sciences. 2016;6(2):863-866.

4. Atanassov LM, Shariati MA, Atanassova MS, et al. Phenolic Compoudns In Traditional Bulgarian Medical Plants. Journal of Microbiology, Biotechnology and Food Science. 2016;6(2):858-862.

5. Rostami O, Shariaty MA, Mousavi Khaneghah A. Comparison the Effects of, Modified Ultra Filtered Cheese Whey, Whey Concentrate and Milk powders on the Rheological and Sensory Properties of Dough and Taftoon Bread. Global Journal of Medicinal Plant Research. 2013;1(1):106-110. 
6. Bad Bug Book. (2nd edn). Foodborne Pathogenic Microorganisms and Natural Toxins Handbook. US Food and Drug Administration, USA. 2012 .

7. Koopmans M, Duizer E. Foodborne viruses: an emerging problem. Int $J$ Food Microbiol. 2004;90(1):23-41.

8. Stals A, Baert L, Van Coillie E, et al. Extraction of food-borne viruses from food samples: a review. Int J Food Microbiol. 2012;153(1-2):1-9.
9. Butot S, Putallaz T, Sanchez G. Effects of sanitation, freezing and frozen storage on enteric viruses in berries and herbs. Int J Food Microbiol. 2008;126(1-2):30-35.

10. Rashidzadeh SH, Mohammadlou AR, Shariati MA. An Introduction to radio frequency method: as one of the electro heating method of food preservation. Indian Journal of Research in Pharmacy and Biotechnology. 2016;4(3):113-115. 